The impact of Staphylococcus aureus concentration on the development of pulmonary lesions and cytokine expression after intravenous inoculation of pigs

Sørensen, Karen Elisabeth; Skovgaard, Kerstin; Heegaard, Peter M. H.; Jensen, Henrik Elvang; Nielsen, Ole Lerberg; Leifsson, Páll S.; Olsen, Helle Gerda; Aalbæk, Bent;

Kristensen, Annemarie Thuri; Kjelgaard-Hansen, Mads; Wiinberg, Bo; Iburg, Tine Moesgaard

Published in:

Veterinary Pathology

DOI:

$10.1177 / 0300985812439726$

Publication date:

2012

Document version

Early version, also known as pre-print

Citation for published version (APA):

Sørensen, K. E., Skovgaard, K., Heegaard, P. M. H., Jensen, H. E., Nielsen, O. L., Leifsson, P. S., Olsen, H. G., Aalbæk, B., Kristensen, A. T., Kjelgaard-Hansen, M., Wiinberg, B., \& Iburg, T. M. (2012). The impact of Staphylococcus aureus concentration on the development of pulmonary lesions and cytokine expression after intravenous inoculation of pigs. Veterinary Pathology, 49(6), 950-962.

https://doi.org/10.1177/0300985812439726 


\section{Veterinary Pathology Online}

\section{The Impact of Staphylococcus Aureus Concentration on the Development of Pulmonary Lesions and}

Cytokine Expression After Intravenous Inoculation of Pigs

K. E. Soerensen, K. Skovgaard, P. M. H. Heegaard, H. E. Jensen, O. L. Nielsen, P. S. Leifsson, H. G. Olsen, B. Aalbaek, A. T. Kristensen, M. Kjelgaard-Hansen, B. Wiinberg and T. M. Iburg Vet Pathol 2012 49: 950 originally published online 28 March 2012

DOI: $10.1177 / 0300985812439726$

The online version of this article can be found at:

http://vet.sagepub.com/content/49/6/950

\section{Published by: \\ (9)SAGE}

http://www.sagepublications.com

On behalf of:

American College of Veterinary Pathologists, European College of Veterinary Pathologists, \& the Japanese College of Veterinary Pathologists.

Additional services and information for Veterinary Pathology Online can be found at:

Email Alerts: http://vet.sagepub.com/cgi/alerts

Subscriptions: http://vet.sagepub.com/subscriptions

Reprints: http://www.sagepub.com/journalsReprints.nav

Permissions: http://www.sagepub.com/journalsPermissions.nav

>> Version of Record - Nov 7, 2012

OnlineFirst Version of Record - Mar 28, 2012

What is This? 


\title{
The Impact of Staphylococcus Aureus Concentration on the Development of Pulmonary Lesions and Cytokine Expression After Intravenous Inoculation of Pigs
}

Veterinary Pathology

49(6) 950-962

(C) The Author(s) 2012

Reprints and permission:

sagepub.com/journalsPermissions.nav DOI: I0.I I77/03009858|2439726

http://vet.sagepub.com

\author{
K. E. Soerensen', K. Skovgaard ${ }^{2}$, P. M. H. Heegaard ${ }^{2}$, \\ H. E. Jensen', O. L. Nielsen', P. S. Leifsson', H. G. Olsen', \\ B. Aalbaek', A. T. Kristensen ${ }^{3}$, M. Kjelgaard-Hansen ${ }^{3}$, \\ B. Wiinberg ${ }^{3}$, and T. M. Iburg ${ }^{1,4}$
}

\begin{abstract}
Acute respiratory distress syndrome is a common complication in severe sepsis. In pigs, the lungs play an important role in clearing systemic bacterial infections due to pulmonary intravascular macrophages found specifically in pigs. However, this increases the exposure of the porcine lungs to pathogens and potential injury. The authors propose that increasing the concentration of the inoculum without changing the bacterial dose will lead to severe sepsis with pronounced pulmonary lesions. This could potentially create a risk of cytokine spillover to the circulation, leading to an increased systemic response. Eight Danish Landrace pigs, approximately 10 weeks old, were inoculated twice with a low or once with a high concentration of Staphylococcus aureus. Three pigs were sham-inoculated. The animals were grouped based on macro- and microscopic lung lesions. The mRNA expression of local pulmonary inflammatory markers was compared to protein levels of systemic inflammatory markers. The most severe pulmonary lesions were observed in animals receiving the high S. aureus concentration, indicating that severity of lesions is dependent on inoculum concentration rather than total numbers of bacteria. Furthermore, local mRNA expression of inflammatory cytokines appeared to be dependent on the magnitude and severity of tissue destruction, including the ability to confine the lesions. Increasing mRNA levels of serum amyloid A could be a confident marker of severity of pulmonary lesions. Since no correlation was observed between local and systemic levels of inflammatory cytokines, this finding could indicate an ability of the porcine lung to compartmentalize the local inflammatory response and thus restrict systemic contribution.
\end{abstract}

\section{Keywords}

bacterial concentration, cytokine, histopathology, lung, RT-qPCR, porcine model, Staphylococcus aureus, swine

Sepsis is a major cause of death in intensive care units (ICUs), and an increasing number of cases is caused by the Grampositive bacterium Staphylococcus aureus. ${ }^{5,34,39}$ Sepsis is the body's systemic response to the presence of pathogens and is caused by complicated self-reinforcing intrinsic cascade reactions that can further progress into severe sepsis with multiple organ dysfunction and septic shock. ${ }^{11,33}$ Organ dysfunction manifested by acute lung injury (ALI) or the more severe form, acute respiratory distress syndrome (ARDS), are common complications. ${ }^{1,43}$ The pathogenesis of sepsis is still not fully understood, however pro- and anti-inflammatory cytokines play a major role in both the local and systemic responses. Tumor necrosis factor $\alpha(\mathrm{TNF} \alpha)$ and interleukin (IL)-1 $\beta$ are important pro-inflammatory cytokines in the systemic response, whereas IL-6, a main initiator of the acute phase protein response, has dual properties, also initiating an antiinflammatory response together with IL- $10 .^{7}$ Local production of IL-8 is responsible for neutrophil migration into the lung tissue $\mathrm{e}^{7,24}$ and plays, in combination with the other cytokines, an important role in regulating the local inflammatory reaction. In a review by Bone it was proposed that exceeding critical concentrations of local cytokines may lead to systemic spillover and an increased systemic inflammatory response. ${ }^{10}$

\footnotetext{
' Department of Veterinary Disease Biology, Faculty of Life Sciences, University of Copenhagen, Denmark

${ }^{2}$ Innate Immunology Group, National Veterinary Institute, Technical University of Denmark, Denmark

${ }^{3}$ Department of Small Animal Clinical Sciences, Faculty of Life Sciences, University of Copenhagen, Denmark

${ }^{4}$ Department of Pathology and Wildlife Disease, National Veterinary Institute, Sweden
}

Corresponding Author:

Karen Elisabeth Soerensen, Department of Veterinary Disease Biology, Ridebanevej 3, I870 Frederiksberg, Denmark

Email: kes@life.ku.dk 
Table I. Experimental Setup: Overview of Animals, Bacterial Concentration in the Inoculums, Time and Numbers of Inoculations, and Time of Euthanasia

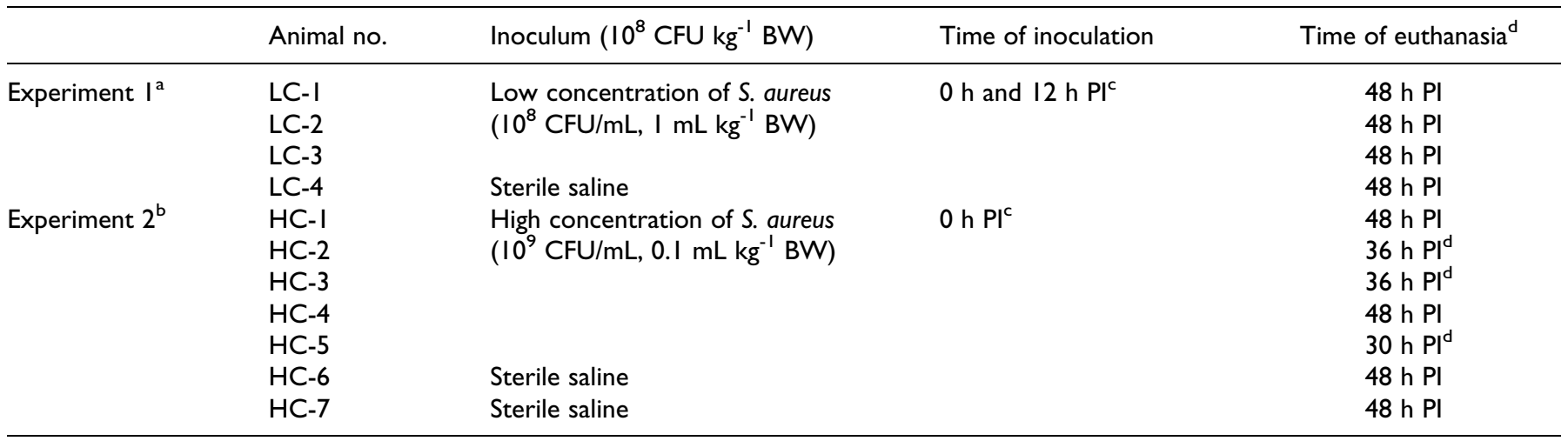

${ }^{\mathrm{a} L C}$, low concentration.

${ }^{\mathrm{b}} \mathrm{HC}$, high concentration.

CPI, post inoculation.

${ }^{\mathrm{d} D u e}$ to ethical reasons, one infected animal was euthanized at $30 \mathrm{~h} \mathrm{PI}$ (HC-5) and two at $36 \mathrm{~h} \mathrm{PI}$ (HC 2-3).

Such spillover of TNF $\alpha$ from the lung has been shown after damage to the alveolar epithelium. ${ }^{29,50}$

Sepsis can be induced in animal models by intravenous (iv) inoculation using several approaches. Previous studies with lipopolysaccharide (LPS) or bacterial suspensions have tested the effect of bolus, continuous infusion, and increasing dosage. ${ }^{32,37,38,44}$ All studies thoroughly describe the dose of the inoculum, namely, the number of bacteria or colony forming units (CFU) given per kg body weight (BW), but information on the volume of the bacterial suspension and thereby the administered bacterial concentration is often sparse. Few have tested the effect of increasing the concentration by decreasing the volume of the suspension, without changing the total number of bacteria administered. Following iv administration of $S$. aur$e u s$, pigs are prone to develop sepsis with incipient signs of acute lung injury. ${ }^{27,32,38}$ Compared to other animal species, the porcine lung plays an important role in clearing systemic bacterial infections, ${ }^{15,41}$ a result of the presence of a high number of pulmonary intravascular macrophages (PIMs). ${ }^{52}$ These PIMs are apposed closely to the capillary endothelium where they phagocytise particulate elements such as bacteria in the blood. However, this may also increase the exposure of the porcine lung to pathogens and potential injury. ${ }^{52}$ PIMs are not normally found in humans, ${ }^{35,52}$ but it is speculated that they can be induced under certain conditions of acute pulmonary inflammation. ${ }^{17,26,45,48}$

In this article, concentration dependent pulmonary lesion after inoculation with either low or high concentration of $S$. aureus in pigs is reported. In addition, the effect of the administered bacterial concentration on the local mRNA cytokine response and the systemic protein concentration of cytokines were compared. We propose that increasing the concentration, without changing the bacterial dosage of the inoculum, would lead to a more severe inflammatory response, mimicking ICU patients with sepsis-induced multiple organ dysfunctions; especially those with deteriorating pulmonary changes. It was examined whether a spillover of pro- and anti-inflammatory cytokines from the lungs could be the leading cause of an increased systemic response.

\section{Materials and Methods}

Materials from two different experiments (Experiment 1 and Experiment 2) were used in this study. Animals in Experiment 1 were inoculated twice with a low concentration (LC) and animals in Experiment 2 once with a high concentration (HC) of S. aureus. All animals were obtained from the same specific pathogen free (SPF) herd, randomly selected based on general appearance and absence of obvious clinical symptoms. The experimental setup is displayed in Table 1 . The $S$. aureus strain used (isolate No. S54F9) was originally isolated from a chronic embolic porcine lung abscess. ${ }^{32}$ Preparation of the inoculum is described in detail by Nielsen et al. ${ }^{38}$ Licences for both experiments were provided by the Danish National Animal Experimentation Board, Ministry of Justice, Denmark (License No. 2008/561-1465), and the animals were treated in accordance with the Council of Europe Convention ETS 123.

\section{Experiment I-Inoculation With a Low Concentration of S. Aureus}

Four female pigs, all clinically healthy SPF crossbreeds (Danish Landrace, Yorkshire, Duroc) with a BW of 20 to $25 \mathrm{~kg}$ and an approximately age of 10 weeks, were used. After an acclimatization period of 7 days, 3 pigs (LC 1-3) were inoculated intravenously with a saline suspension of $10^{8} \mathrm{CFU}$ S. aureus pr. $\mathrm{mL}$, administrated in a dose of $10^{8} \mathrm{CFU} / \mathrm{kg}$ $\mathrm{BW}$, corresponding to a volume of $1 \mathrm{~mL} / \mathrm{kg} \mathrm{BW}$. The animals were inoculated twice, at $0 \mathrm{~h}$ and again $12 \mathrm{~h}$ later, namely, receiving a total of $2 \times 10^{8} \mathrm{CFU} / \mathrm{kg} \mathrm{BW}$. The control pig (LC 4) was sham-inoculated with the same volume of sterile isotonic sodium chloride at identical time points $(0 \mathrm{~h}$ and $12 \mathrm{~h}$ ). Inoculation occurred over a period of $2 \mathrm{~min}$. Clinical examinations included temperature measurements and blood 
samples performed by venipuncture of the external jugular vein at regular intervals $(0,12,24,36$, and $48 \mathrm{~h}$ post inoculation [PI]). Animals were euthanized at $48 \mathrm{~h}$ PI with an intravenous injection of $20 \%$ pentobarbital. For further detailed description see Leifsson et al ${ }^{32}$ and Jensen et al. ${ }^{27}$

\section{Experiment 2-Inoculation With a High Concentration of $\mathrm{S}$. Aureus}

Seven female clinically healthy SPF crossbreed pigs (Danish Landrace, Yorkshire, Duroc), approximately 10 weeks old with a body weight of 20 to $25 \mathrm{~kg}$, were housed in individual pens for an acclimatization period of 5 to 6 weeks. On arrival all animals were haematologically screened for subclinical infections. When entering the study, the pigs were approximately 15 to 16 weeks old and weighted 33 to $39 \mathrm{~kg}$. Five pigs (HC 1-5) were intravenously inoculated with $S$. aureus. The inoculum was administered in a saline suspension of $1 \times 10^{9} \mathrm{CFU} / \mathrm{mL}$ and was administered intravenously at a dose of $1 \times 10^{8} \mathrm{CFU} / \mathrm{kg} \mathrm{BW}$, corresponding to a volume of $0.1 \mathrm{~mL} / \mathrm{kg} \mathrm{BW}$. Control animals (HC 6-7) were sham-inoculated with sterile isotonic sodium chloride solution by the same method. Inoculation occurred over a period of $1 \frac{1}{2}$ to $2 \mathrm{~min}$. Blood samples were collected from a jugular catheter at regular intervals before (III, II, I, $0 \mathrm{~h}$ ) and after inoculation ( $6 \mathrm{~h}, 12 \mathrm{~h}, 24 \mathrm{~h}, 36 \mathrm{~h}$, and $48 \mathrm{~h} \mathrm{PI})$. Full clinical examination including temperature measurement was carried out every $6 \mathrm{~h} \mathrm{PI}$, and a veterinarian continually supervised the animals for $48 \mathrm{~h}$ PI. Analgesia was established with Butorphanol i.m. (0.2-0.3 mg/kg BW) (Torbugesic ${ }^{\circledR}$, Scanvet, Denmark) every $4 \mathrm{~h}$ from onset of clinical signs of discomfort or obvious pain. At the termination of the experiment, all animals were sedated and euthanized with an overdose of propofol (Rapinovet ${ }^{\mathbb{R}}$, Schering-Plough, Denmark) and exsanguinated by severing the axillary vessels. Due to ethical consideration, 3 infected animals were euthanized prior to expected, 1 at $30 \mathrm{~h} \mathrm{PI}$ (HC-5) and 2 at $36 \mathrm{~h} \mathrm{PI} \mathrm{(HC} \mathrm{2-3).} \mathrm{For} \mathrm{fur-}$ ther details see Soerensen et al. (unpublished data, 2011).

\section{Postmortem Examination}

The lungs and the corresponding tracheobronchial lymph nodes from all pigs were evaluated postmortem. Lung tissues were sampled for histopathology from both a predefined area of the dorsal margin at the right caudal lobe and from areas with gross lesions. Tissues from lungs and lymph nodes were fixed in formalin, processed routinely, and cut in sections of 3 to $4 \mu \mathrm{m}$. Sections were stained with haematoxylin and eosin (HE) for overall evaluation, Masson trichrome for detection of collagen, and phosphotungstic acid haematoxylin (PTAH) for fibrin. ${ }^{4}$ Furthermore, sections were immunostained for cytokeratin to identify epithelium, ${ }^{46}$ fibrinogen/fibrinogen-fragments D and $\mathrm{E},{ }^{30} \mathrm{CD}-3 \varepsilon$ a surface marker to indetify $\mathrm{T}$ cells, ${ }^{31}$ lysozyme to identify macrophages, ${ }^{20}$ and intracytoplasmatic antigen (L1-antigen) in neutrophils, monocytes, and tissue macrophages. ${ }^{30}$ The bacteria, $S$. aureus, was identified in situ as previously described. ${ }^{28}$ Immunohistochemical detection of IL-8 was performed with mouse anti sheep IL-8 monoclonal antibody, clone 8M6 (MCA1660, AbD Serotec, UK). This antibody has previously been reported to show cross-reactivity to swine IL-8 in flow cytometry and Western blot analysis. ${ }^{40}$ Briefly, antigen retrieval was done by microwave heating in a buffer containing 0.01 M Tris buffer grade (A1379, Applichem, USA) and 0.0005 M EGTA (E3889, Sigma-Aldrich, Denmark) at $\mathrm{pH}$ 9.0. This was followed by overnight incubation at $4{ }^{\circ} \mathrm{C}$ with the primary monoclonal antibody $(1 \mu \mathrm{g} / \mathrm{ml})$. Detection was performed using the ultravision LP detection system HRP Polymer (Thermo Fisher Scientific, CA, USA), with the chromogen AEC-red (Thermo Fisher Scientific) and counterstained with Mayer's hematoxylin. Tissue from a severely affected lung (HC-2) were used as positive control and lung tissue from a sham-inoculated animal (HC-7) as negative control, furthermore unspecific binding were excluded by replacement of the primary antibody by an irrelevant monoclonal antibody of identical isotype and concentration (mouse IgG2a negative control, X0943, Dako A/S, Denmark).

Tissue samples were taken for reverse transcription quantitative real-time PCR (RT-qPCR) detection of mRNA levels from the dorsal margin of the left caudal lobe and fixed in an RNA preserving solution (40 mL 0.5 M EDTA, $25 \mathrm{~mL} 1 \mathrm{M}$ sodium citrate, $700 \mathrm{~g}$ ammonium sulfate, $935 \mathrm{~mL}$ sterile distilled water, adjustment to $\mathrm{pH} 5.2$ using $\mathrm{H}_{2} \mathrm{SO}_{4}$ ). The tissue samples were stored for $24 \mathrm{~h}$ at $2^{\circ} \mathrm{C}$ to $8^{\circ} \mathrm{C}$ and thereafter at $-20^{\circ} \mathrm{C}$.

Grouping of lung lesions. The pigs were divided into five groups (A, B, C, D, and E) based on the macroscopical evaluation of distribution, number of abscesses (none or a few $\leq 5$, moderate $<25$, or many $\geq 25$ ) and presence of necrosis combined with a histopathological evaluation of the severity of the lesions (delineated or nondelineated) and influence on the alveolar tissue (local or extensive) (Table 2).

\section{Microbiology}

Quantitative microbiological examination was performed on heparin stabilized blood $(4 \mathrm{~mL})$ from both experiments, as previously described. ${ }^{38}$ Lung tissues from the right caudal lobe were sampled aseptically for bacterial re-isolation of $S$. aureus. $^{27,38}$

\section{Clinical Pathology}

Hematology. White blood cell (WBC) counts and total neutrophil (PMN) counts were conducted on EDTA stabilized whole blood sampled from both experiments (ADVIA 120 analyzer, Bayer Healthcare Diagnostics, Germany).

Systemic cytokines and acute phase proteins. Serum collected from each experiment were evaluated for protein levels of $\mathrm{TNF} \alpha$, IL-1 $\beta$, and IL- 6 , according to Nielsen et al. ${ }^{38}$ In addition, the anti-inflammatory IL-10 was determined by a sandwich ELISA using mouse anti porcine IL-10 for catching and biotinylated goat anti pig IL-10 for detection following the recommendations of the manufacturer (Duoset ELISA, catalog 
Table 2. Distribution of Pigs into 5 Groups (A, B, C, D, and E) Based on Gross Lesions and Histopathology

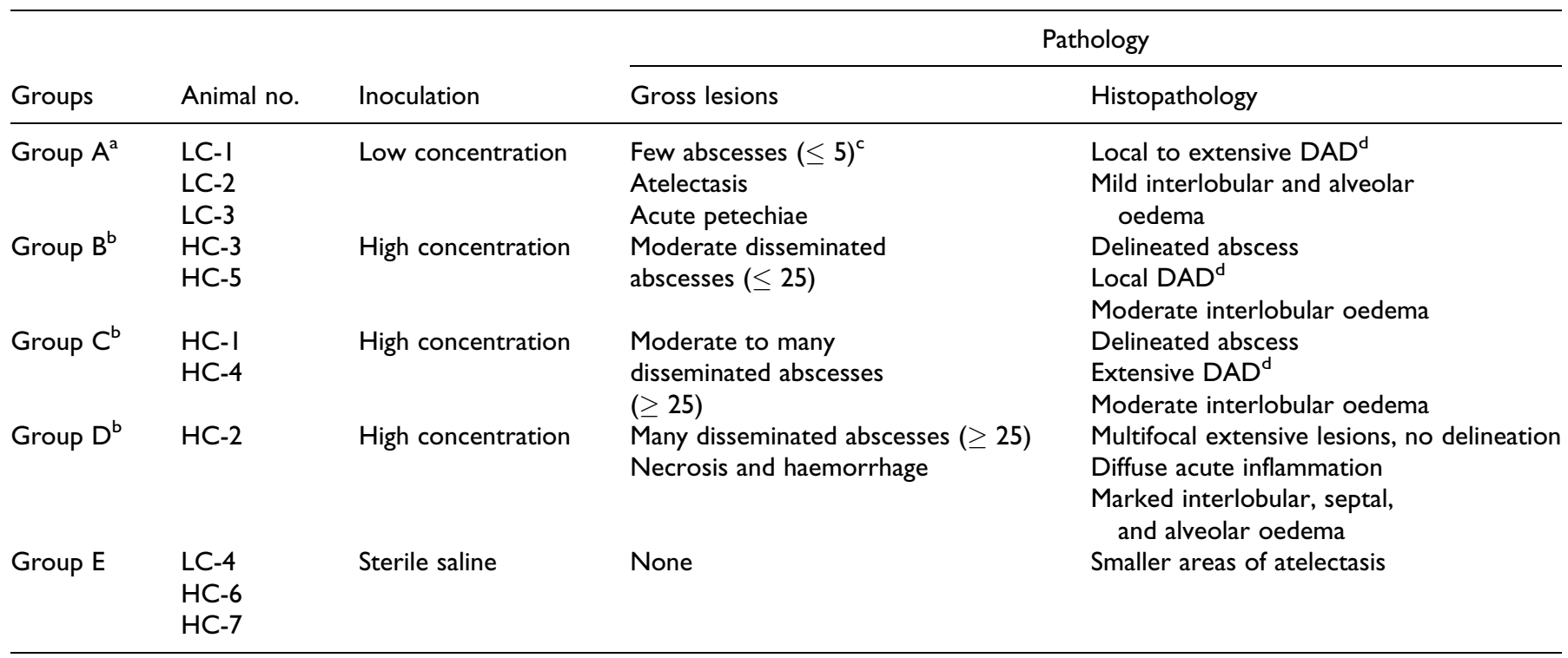

${ }^{\mathrm{a}} \mathrm{LC}$, low concentration.

${ }^{\mathrm{b}} \mathrm{HC}$, high concentration.

${ }^{\mathrm{C}}$ Abscesses were only observed in the lungs of one animal (LC-2) in the low concentration group.

DAD, diffuse alveolar damage characterized by thickening of interalveolar septa by inflammatory cells and oedema.

No. DY693, R\&D Systems, UK). A recombinant porcine IL-10 (R\&D Systems) standard was included. Development of plates was performed following incubation with peroxidase-coupled streptavidin with a tetramethylbenzidine (TMB) peroxide color substrate (TMB X-tra, catalog No. 4800-T, Kem-En-Tec, Denmark) according to the manufacturer's instructions. All samples were run in duplicates in a dilution of 1:2 with the following detection limits: $0.0468 \mathrm{ng} / \mathrm{mL}$ (TNF $\alpha$ ), $0.031 \mathrm{ng} / \mathrm{mL}$ (IL-6), 0.25 $\mathrm{ng} / \mathrm{mL}$ (IL-1 $\beta$ ), and $0.5 \mathrm{ng} / \mathrm{mL}$ (IL-10). C-reactive protein (CRP) and haptoglobin (Hp) were analyzed according to previously validated methods. ${ }^{22,23}$ Correlation between CRP and Hp was calculated using Spearman correlation (GraphPad Prism version 4.00 for Windows, GraphPad Software, CA, USA).

\section{Reverse transcription quantitative real-time PCR detec- tion of $m R N A$ expression of inflammatory markers in the lung}

Lung tissue from all pigs was analyzed by RT-qPCR for mRNA expression levels of IL- $1 \alpha$, IL-1 $\beta$, IL-6, IL-8, TNF $\alpha$, Transferrin (TRF), Hp, and Serum Amyloid A (SAA).

RNA extraction, cDNA synthesis, and pre-amplification. RNA stabilized lung tissues were homogenized, and total RNA was extracted using RNeasy Mini kit (Qiagen, Denmark), according to the manufacturer's instructions. Purity of extracted total RNA was assessed and the amount quantified using a Nanodrop ND-1000 spectrophotometer (Saveen and Werner AB, Sweden). RNA integrity was analyzed on an Agilent 2100 Bioanalyzer (Agilent Technologies, Denmark) using the RNA 6000 Nano Kit. Extracted RNA was converted into cDNA by reverse transcription of $500 \mathrm{ng}$ total RNA by QuantiTECT
Reverse Transcription kit (Qiagen), using a mix of random primers and oligo-dT. cDNA was diluted 1:6 in low EDTA TEbuffer (VWR - Bie \& Berntsen, Denmark) prior to preamplification. TaqMan PreAmp Master Mix $(5 \mu \mathrm{L})$ (Applied Biosystems, Denmark) was mixed with $2.5 \mu \mathrm{L} 200 \mathrm{nM}$ pooled primer mix (prepared by combining equal concentration of all primers used in the present study) and $2.5 \mu \mathrm{L}$ diluted cDNA and incubated at $95^{\circ} \mathrm{C}$ in $10 \mathrm{~min}$ followed by 15 cycles of $95^{\circ} \mathrm{C}$ in $15 \mathrm{sec}$ and $60^{\circ} \mathrm{C}$ in $4 \mathrm{~min}$. Pre-amplified cDNA was diluted at least 1:4 in low EDTA TE-buffer (VWR - Bie \& Berntsen) before quantitative real-time PCR (qPCR). Primers were designed using Primer3 (http://frodo.wi.mit.edu/) as described in Skovgaard et $\mathrm{al}^{46}{ }^{46}$ and synthesized at TAG Copenhagen (Denmark). Primer sequences, amplicon length, and primer PCR efficiency are shown in Table 3.

qPCR. qPCR was performed in 48.48 Dynamic Array Integrated Fluidic Circuits (Fluidigm, CA, USA). The following components were used for 48 reactions (sample mix): $3 \mu \mathrm{L} \mathrm{ABI}$ TaqMan Gene Expression Master Mix (Applied Biosystems), 0.3 $\mu \mathrm{L}$ 20X DNA Binding Dye Sample Loading Reagent (Fluidigm), $0.3 \mu \mathrm{L} 20 \mathrm{X}$ EvaGreen (Biotium, VWR - Bie \& Berntsen), and $0.9 \mu \mathrm{L}$ low EDTA TE Buffer (VWR - Bie \& Berntsen). Sample mix $(4.5 \mu \mathrm{L})$ was mixed with $1.5 \mu \mathrm{L}$ pre-amplified cDNA. Primer mix (48 reactions) was prepared using $2.3 \mu \mathrm{L} 20 \mu \mathrm{M}$ primer set (Table 3), $2.5 \mu \mathrm{L} 2 \mathrm{X}$ Assay Loading Reagent (Fluidigm), and $0.2 \mu \mathrm{L}$ low EDTA TE-buffer (VWR - Bie \& Berntsen). Sample mix, including cDNA $(5 \mu \mathrm{L})$ and primer mix $(5 \mu \mathrm{L})$, was dispensed into appropriate inlets and loaded into the chip (Fluidic Circuit of the Dynamic array) in the IFC Controller (Fluidigm). The chip was placed in the BioMark real-time PCR instrument (Fluidigm), and the following cycle parameters were used: $2 \mathrm{~min}$ at $50^{\circ} \mathrm{C}, 10 \mathrm{~min}$ at $95^{\circ} \mathrm{C}$, followed by 35 cycles with denaturing 
Tabel 3. Primers Used for Quantitative Real-Time PCR (qPCR)

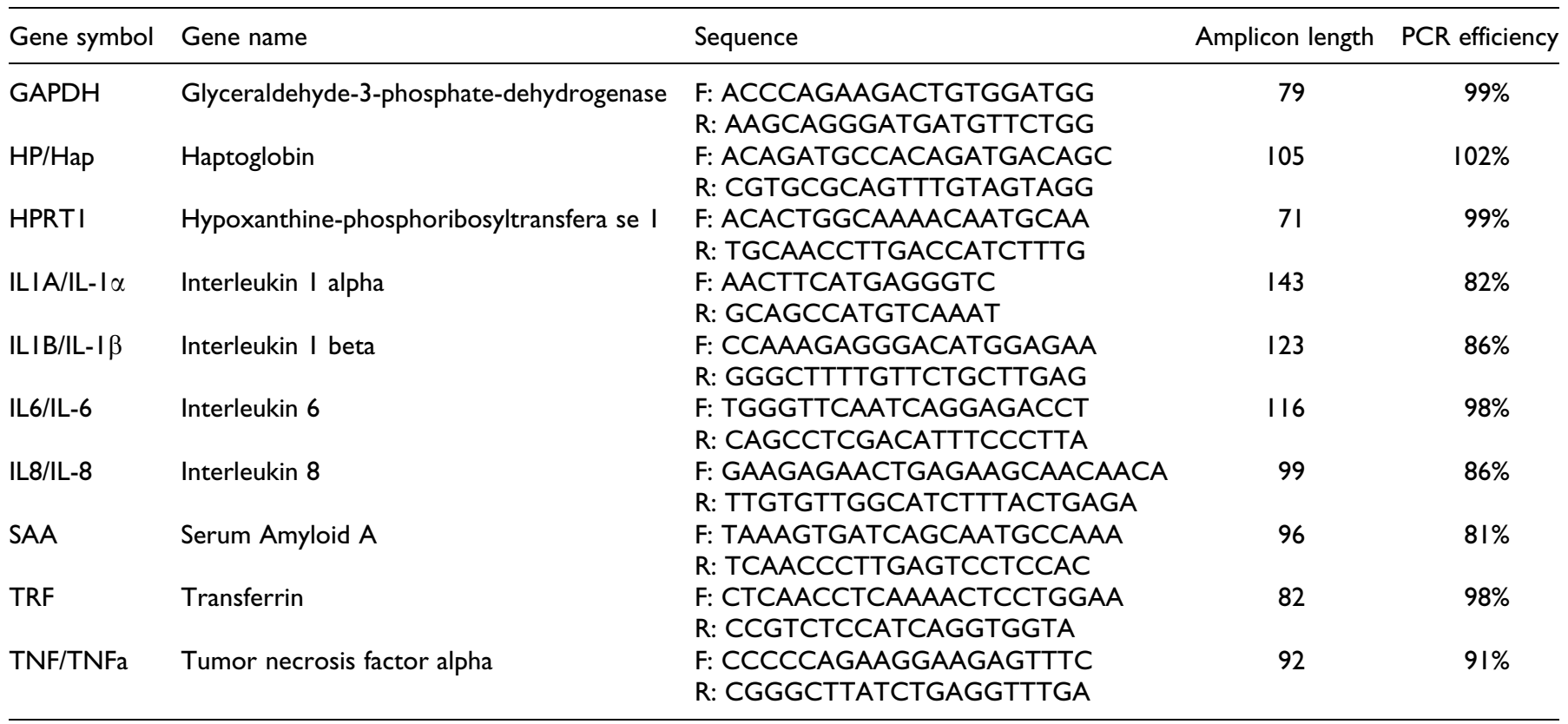

for $15 \mathrm{~s}$ at $95^{\circ} \mathrm{C}$ and annealing/elongation for $1 \mathrm{~min}$ at $60^{\circ} \mathrm{C}$. Melting curves were generated after each run to confirm a single PCR product (from $60^{\circ} \mathrm{C}$ to $95^{\circ} \mathrm{C}$, increasing $1^{\circ} \mathrm{C} / 3 \mathrm{~s}$.). Reactions were performed in duplicates (qPCR replicates). Nontemplate controls (NTCs) were included to indicate potential problems with nonspecific amplification or sample contaminations. Data were acquired using the Fluidigm Real-Time PCR Analysis software 3.0.2 (Fluidigm) and exported to GenEx (MultiD, Göteborg, Sweden) for further analysis.

RT-qPCR data analysis. Data pre-processing, normalization, relative quantification, and statistics were performed using GenEx5. Data were pre-processed as follows: (1) Data were corrected for PCR efficiency for each primer assay individually; (2) average of technical repeats was calculated before reference gene normalization; (3) hypoxanthine phosphorribosyl-transferase 1 (HPRT1) and glyceraldehyde3-phosphate dehydrogenase (GAPDH) were found to be the most stably expressed reference genes in the present study using both GeNorm ${ }^{51}$ and NormFinder, ${ }^{2}$ thus the geometric mean of these two genes was used to normalize all samples in GenEx. For each primer assayed, relative mRNA expression levels for all the samples were calculated relative to the control group. Data was $\log _{2}$ transformed to approach normal distribution prior to $t$-test. Gene expression was considered to be significant if the $P$-value $<.05$ and fold change $> \pm 2.0$.

\section{Results}

\section{Evaluation of Lung Pathology}

Grouping of animals (A, B, C, D, and E) according to the degree of macro- and microscopical lung lesions is presented in Table 2.
Group A. Gross lesions were characterized by areas of atelectasis with acute petechiae. In one animal (LC-2) a few abscesses $(2 \mathrm{~mm})$ with hemorrhagic margins were observed in the right cranial lobe. In sections from predefined areas, local to more extensive alveolar affection was observed microscopically, characterized by mild alveolar oedema, an increased number of alveolar macrophages, atelectasis, and thickening of the alveolar septa by mild inflammation and oedema. Mild dilation of capillaries and medium sized vessels with congestions and thrombosis was present. Interlobular oedema and mild dilation of lymph vessels were seen in all animals of the group. Only one abscess was identified microscopically in a section taken from an area with gross lesions (LC-2). All pigs infected with the low concentration of $S$. aureus were included in this group (LC 1-3) (Fig. 1).

Group B. A moderate number of bilateral pulmonary disseminated abscesses, some with an acute hemorrhagic margin, were seen macroscopically. In histological sections from predefined areas, abscesses with clear delineation from the surrounding tissue were presented. Thickening of alveolar septa was observed in the local area surrounding the abscesses, along with an increased number of alveolar macrophages. Moderate interlobular oedema with fibrinogen/fibrinogen-fragments and dilation of lymphatic vessels was present. Small amounts of fibrin were found in congested arteries. In HC-5, thrombosis was seen in medium sized vessels at the abscess periphery. In $\mathrm{HC}-3$, lesions were more acute with marked hyperaemia and congestion of capillaries and medium sized blood vessels. Pig $\mathrm{HC}-3$ and HC-5 were included in this group (Fig. 2).

Group C. Moderate to many disseminated bilaterally distributed abscesses occasionally associated with necrotic areas were present in the lungs. Microscopical evaluation of sections from 


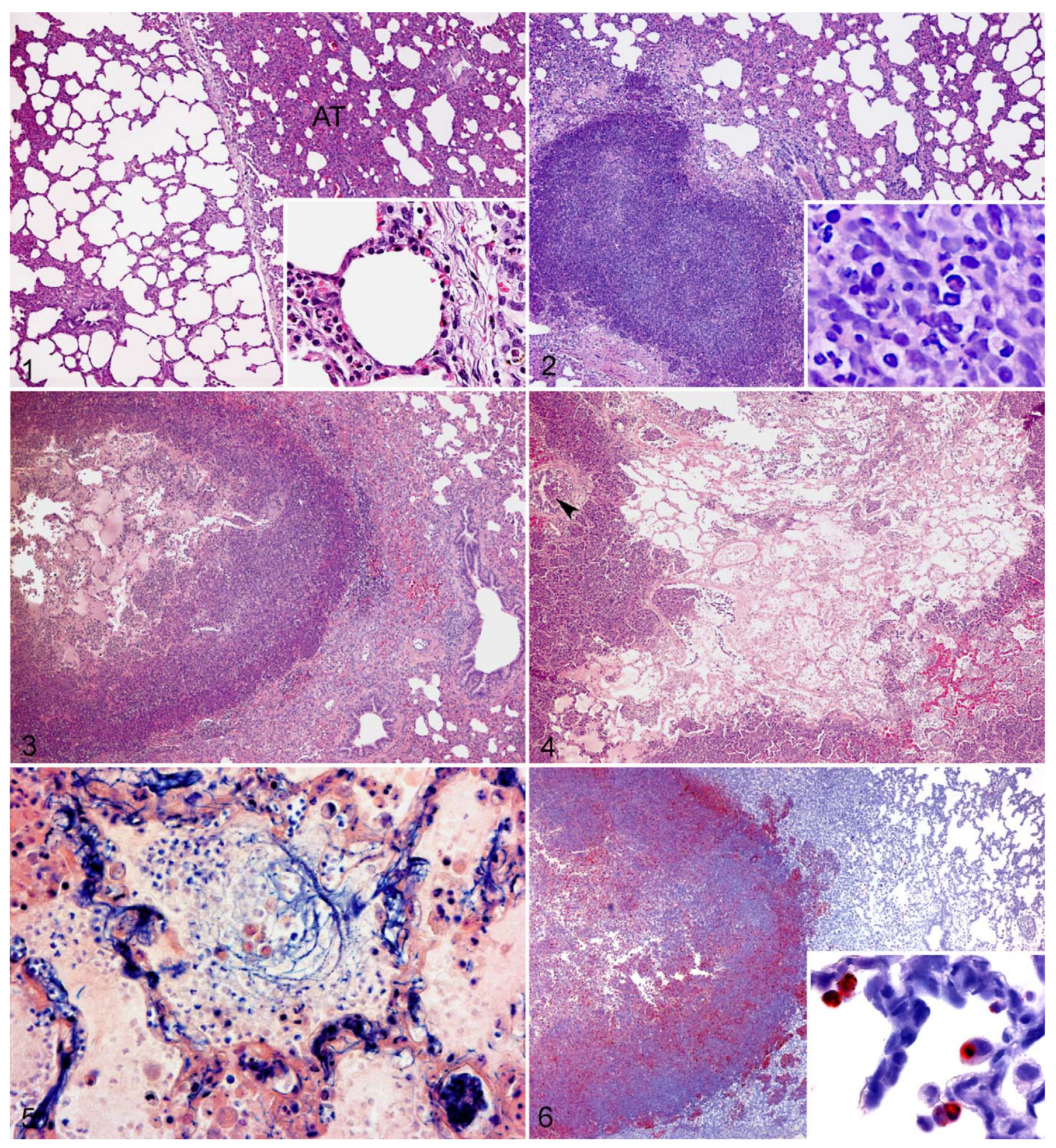

Figure I. Porcine lung; Group A (LC-I). Areas of atelectasis (AT). Haematoxylin and eosin (HE). Insert shows mild thickening of inter-alveolar septa, intra-capillary neutrophil accumulation, and mild interlobular oedema. HE. Figure 2. Porcine lung; Group B (HC-5). Clearly delineated abscess with local affection of surrounding inter-alveolar septa. Haematoxylin and eosin (HE). Insert shows mixed inflammatory cells, representing the typical cell population in the periphery of the abscesses. HE. Figure 3. Porcine lung; Group C (HC-I). Clearly delineated abscess with central necrosis. Affection of inter-alveolar septa in the whole section. Capillary congestion. Haematoxylin and eosin (HE). Figure 4. Porcine lung; Group D (HC-2). Extensive lesions with no clear delineation. Infiltration of inflammatory cells, necrotic cellular debris, and intra-alveolar exudation. There is spread of inflammatory cells to the conducting system (arrowhead). Capillary congestion. Haematoxylin and eosin (HE). Figure 5. Porcine lung; Group D (HC-2). Fibrin accumulation in alveoli and alveolar septa. Thrombosis is seen in a small artery in the right corner. Phosphotungstic acid haematoxylin (PTAH). Figure 6. Porcine lung; HC group (HC-4). Distribution of IL-8 immunohistochemical staining in abscesses of the HC Group. IL-8 and Mayer's hematoxylin counterstain. Insert shows IL-8 positive cells with macrophage morphology and intracytoplasmatic staining. IL-8 and Mayer's hematoxylin counterstain 
predefined areas showed clearly delineated abscesses with surrounding moderate septal inflammation extending to all alveolar septa in the section. Dilatation of lymph vessels and moderate interlobular oedema containing fibrinogen/ fibrinogen-fragments and smaller amounts of fibrin were seen. Vascular congestion with a proteinaceous homogeneous appearance, fibrinogen/fibrinogen-fragments, and some fibrin were present. Furthermore, minor areas of alveolar exudation containing erythrocytes, neutrophils, and mononuclear cells were found in one animal (HC-4). Pigs HC-1 and HC-4 were included in this group (Fig. 3).

Group D. Disseminated, necrotizing, and hemorrhagic abscesses were seen bilaterally, along with marked oedema and acute fibrinous pleuritis. Microscopically, extensive acute lesions without clear delineation were seen in sections taken from predefined areas. Acute severe suppurative inflammation with necrotic cellular debris and fibrinous exudation was seen in the alveoli with spreading to the conducting system (Fig. 4). Marked interlobular, septal, and alveolar oedema with fibrinogen/fibrinogen-fragments and fibrin exudation was found (Fig. 5). All vessels were congested with accumulation of fibrin, and thrombosis was seen in small and medium sized arteries. Lymphatic vessels were distended with fibrinous material, and severe neutrophilic infiltrations were seen especially in subpleural lymph vessels. Pig HC-2 was included in this group (Fig. 4).

Group E. No gross lesions were found. Microscopically, smaller areas of atelectasis were seen in Pigs HC-6 and HC7. Areas of capillary hyperaemia and mild-interlobular oedema were seen in Pig LC-4. All control animals fell into this group (LC-4, HC 6-7).

Well-delineated abscesses were observed as a prevailing histological lesion in three of the groups; one animal (LC-2) in Group A and all animals in Groups B and C. These abscesses were microscopically characterized by a central area of necrotic tissue and cellular debris surrounded by inflammatory cells. In most abscesses, S. aureus was demonstrated centrally. Oat-shaped cells created a darker condensed necrotic edge at the abscess periphery, surrounded by small mononuclear cells (identified as immature macrophages by morphology, positive staining for L1-antigen, and lack of CD-3 $\varepsilon$ staining) filling the alveolar spaces. All abscesses contained lysozyme positive fragments or cells at the periphery, together with strongly positive IL-8 stained cells, some with a fragmented or a granular appearance (Fig. 6). Fibrinogen/fibrinogen-fragments and fibrin were seen in relation to the periphery of the abscesses. All abscesses were acute with no signs of granulation tissue and located either interlobularily or expanding from the alveolar septa. Increasing numbers of lysozyme positive macrophages, some with IL-8 positive intracytoplasmatic granules, were found within the alveolar septa, alveoli, conducting system, and vascular structures in the HC groups (Fig. 6). All infected animals showed a mild increase in T-lymphocyte infiltration, in association with bronchus-associated lymphoid tissue (BALT) and bordering the abscesses in Groups B and C.

In Pig HC-2 (Group D), increasing amounts of the aforementioned cell types were present with a more extensive distribution pattern, exemplified by a diffuse IL- 8 response with spreading of positive cell material to the conducting system. Furthermore, a few positive $S$. aureus clusters were found scattered in the lesions. Increased amounts of L1-antigen positive cells, lysozyme stained macrophages, and T-lymphocytes were found in the conducting system, interlobularily, in lymphatic vessels, and peri- and intravascularily.

\section{Histopathological Evaluation of the Tracheobronchial Lymph Nodes}

Marked neutrophil accumulations were observed in the tracheobronchial lymph nodes of Groups B, C, and D receiving the high $S$. aureus concentration. Neutrophil infiltrations were primarily localized peripheral to trabecular structures and in the subcapsular sinus. Lesions varied from haemorrhage and microabscess formation (HC-5) to diffuse neutrophil infiltration (HC 1-4). Lymph vessels were distended and the tissue oedematous. Fibrin was seen in trabecular and subcapsular sinuses in most pigs. Hemorrhage, severe congestion, and thrombosis in blood and lymphatic vessels were found in one pig (HC-2). In animals receiving the low $S$. aureus concentration (Group A) areas of subcapsular hemorrhage and mild neutrophil infiltration were found. In one animal (LC-1) a macroscopically visible abscess was observed, and in another (HC-1) a large abscess was observed by histology. One animal (LC-3) showed no significant reaction in the lymph nodes. No reactions were seen in the tracheobronchial lymph nodes of the control animals (Group E).

\section{Microbiology}

Pulmonary S. aureus counts appeared to increase with the severity of lesions, with the highest bacterial count found in Group D, followed by Group C. Approximately identical mean bacterial counts were seen in Groups A and B (Fig. 7). S. aureus was not isolated from any of the control samples (Group E).

\section{Systemic Inflammatory Markers}

A marked rise in body temperature was observed between 6 and $12 \mathrm{~h}$ PI in animals from both inoculated groups, and the temperature remained elevated during the rest of the experiment (Fig. 8). Regardless of the bacterial concentration of the inoculum, neutrophilia were present in all infected animals during the first $6 \mathrm{~h}$, peaking at $12 \mathrm{~h}$ to $24 \mathrm{~h}$ (Fig. 9).

Increasing systemic IL-6 protein concentrations were observed between $6 \mathrm{~h}$ and $12 \mathrm{~h}$ PI in all infected animals and remained elevated throughout the experimental period (Fig. 10). Serum protein concentrations of CRP and Hp also increased, with CRP increasing earlier than Hp in most infected animals (Figs. 12, 13). A highly positive correlation was seen between CRP and Hp levels $(P<.0001)$. Small transient peaks 


\section{Pulmonary bacterial count}

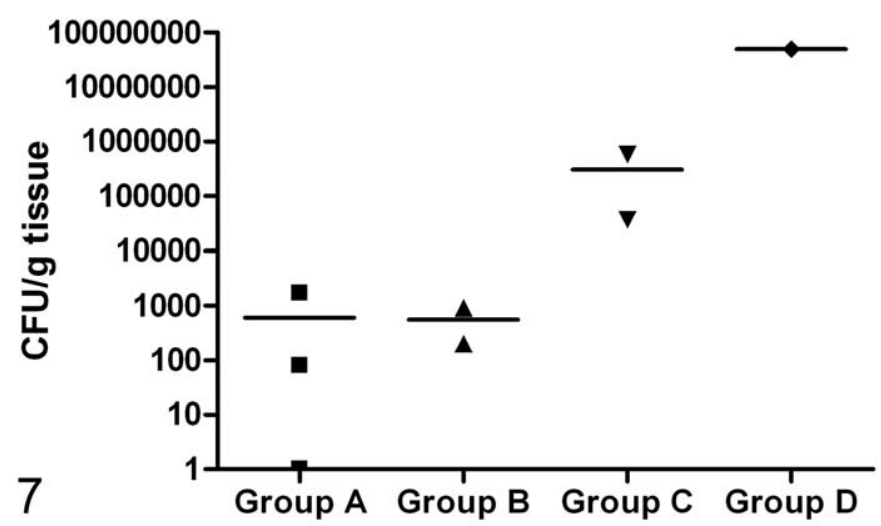

Figure 7. Pulmonary bacterial count of S. aureus (CFU/g tissue). Lines show mean values and symbols show the value of the individual pigs assigned to the Groups $A, B, C$, and $D(\boldsymbol{\square}, \boldsymbol{\Delta}, \boldsymbol{\nabla}, \boldsymbol{\bullet})$. No S. aureus were found in the lungs of the control animals (Group $E$ ).

of TNF $\alpha$ were observed at $6 \mathrm{~h}$ PI (Fig. 11) but only in infected animals from Experiment 2 (HC groups) with blood sampled at $6 \mathrm{~h}$ PI. At the end of the study (48 h PI) TNF $\alpha$ protein values of most infected pigs were below values of control animals. Systemic protein levels of IL-1 $\beta$ and IL-10 did not exceed the detection limit.

\section{Local Pulmonary Inflammatory Markers}

Mean relative mRNA expression of selected pro-inflammatory markers in the lungs of animals inoculated with the low or the high concentration of $S$. aureus compared to control animals is presented in Figure 14. mRNA coding for the acute phase protein SAA was found to be significantly up-regulated $(P=.030)$ in the HC group compared to the control group. Likewise, the negative acute phase reactant, TRF, was found to be significantly down-regulated $(P=.022)$ in the HC group compared to the control group. In general, no significant concentration dependent differences were seen in the pro-inflammatory cytokine levels. However, a tendency towards decreasing levels in the LC group and increasing levels in the HC group were observed for the interleukins. The contribution of the individual five groups ( $\mathrm{A}, \mathrm{B}, \mathrm{C}, \mathrm{D}$, and $\mathrm{E})$ to the mean relative mRNA expression levels of the selected pro-inflammatory markers in the lung is shown in Figure 15. A decrease of mRNA coding for the pro-inflammatory cytokines (IL-1 $\alpha$, IL-1 $\beta$, IL-6, IL-8, and $\mathrm{TNF} \alpha$ ) was found in the lung tissue of most groups, except for Group D/HC-2, in which a 2 fold to 8 fold increase compared to the control group was seen for all of the aforementioned proinflammatory cytokines, except for TNF $\alpha$. TNF $\alpha$ mRNA expression appeared to be down-regulated in all groups, with the lowest levels observed in the severely affected Group D/HC-2. In complete contrast to this, SAA expression was stepwise increased in all groups, from more than a 2 fold increase in Group A to an almost 48fold increase in Group D. An increased expression of Hp was seen in all infected groups, except in Group D, where a small decrease was seen.

\section{Discussion}

In this study, a bacterial concentration dependent change in pulmonary lesions and local mRNA expression of inflammatory markers was described. By increasing the concentration of $S$. aureus in the inoculum, more severe pulmonary disease with pronounced gross lesions and histological changes developed in the HC groups (Groups B, C, and D) compared to the LC group (Group A), even though animals in Group A (LC group) received the low concentration dose twice and hereby the double amount of $S$. aureus. ${ }^{27,32}$ Interestingly, despite this difference in total bacterial numbers, the highest mean bacterial count was found in the lungs of the $\mathrm{HC}$ groups with the most pronounced pulmonary lesions (Groups $\mathrm{C}$ and D). When comparing pulmonary lesion between the LC (11 weeks) and the HC group (15-16 weeks), the effect of age difference on immune response should be addressed. No definitive studies have been made to determine the age at which the immune system are fully developed in pigs, but key elements of the immune system are suggested to be present soon after birth. However, different studies have assessed aspects of cellular development and immunoglobulin maturity, indicating that immunity develops at 5 to 7 weeks and are fully developed at 7 to 12 week of age. .,9,18 $^{\text {This validates comparison of pigs }}$ in the LC group with a finished or nearly finished immune response to pigs of the $\mathrm{HC}$ group.

In the LC group (A), a good clearance was evidenced by a low bacterial count in the lung and limited tissue affection, whereas in the two HC groups (group B and C) the clearance capacity of the lungs or more specifically the PIMs appeared to have been exceeded, leading to bacterial containment within focal lesions. However, as the animals of Group B were euthanized at $30 \mathrm{~h}$ and $36 \mathrm{~h} \mathrm{PI}$, respectively, the effect of a time factor on the development of lesions cannot be rejected. It can only be speculated if the lung lesions of Group B would have developed into lesions similar to what was observed in Group C. Despite a similar short lifespan (36 h PI) of the animal in the HC Group D, neither clearance nor focal containment seemed to occur. More extensive lesions with a high pulmonary bacterial count were seen and may reflect an individual host immune response in this animal. Such extensive lesions could increase the risk of cytokine spillover from the lungs to the circulation. ${ }^{10,29,50}$

In other porcine studies, pulmonary clearance has been shown to be dependent on bacterial strain ${ }^{16}$ and dose. ${ }^{15}$ However, this study suggests that the difference in pulmonary clearance ability depends on the bacterial concentration in the inoculum rather than the total number of bacteria injected into the systemic circulation. This emphasizes the importance of reporting the concentration of the inoculum in bacterial infection studies.

Low or decreasing levels of mRNA coding for pulmonary pro-inflammatory cytokines were observed in Groups A 

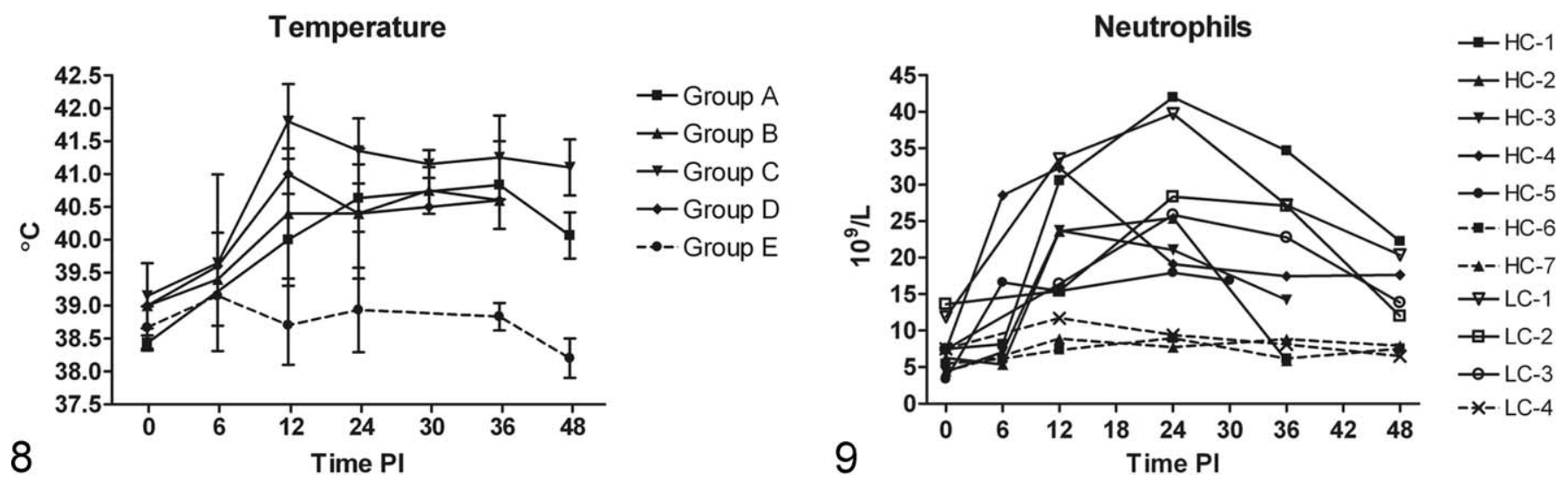

Figure 8. (A) Changes in body temperature in the different groups. Individual variations in the groups are shown by standard deviation (SD) bars. A marked rise in temperature was seen in the infected groups (A, B, C, D) compared to the control group (E). Figure 9. Individual changes in blood neutrophil count. Increased levels were seen in all infected animals, independently of receiving the LC or the HC dose. In both figures, the broken lines represent sham-inoculated control animals and the full lines the infected pigs.

IL-6

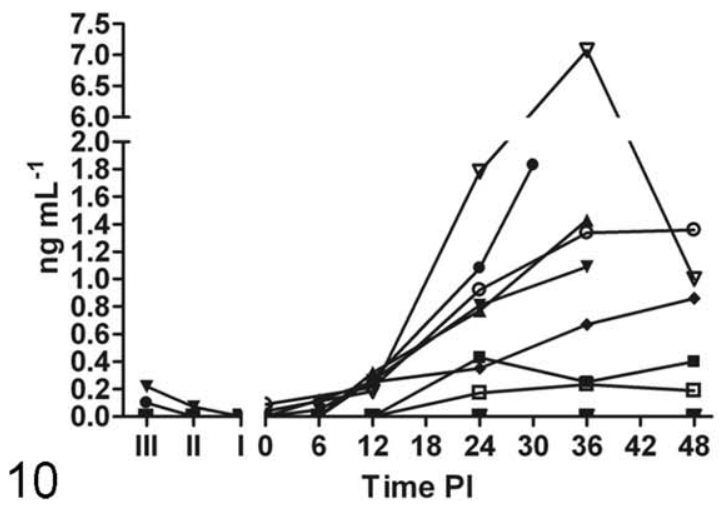

CRP

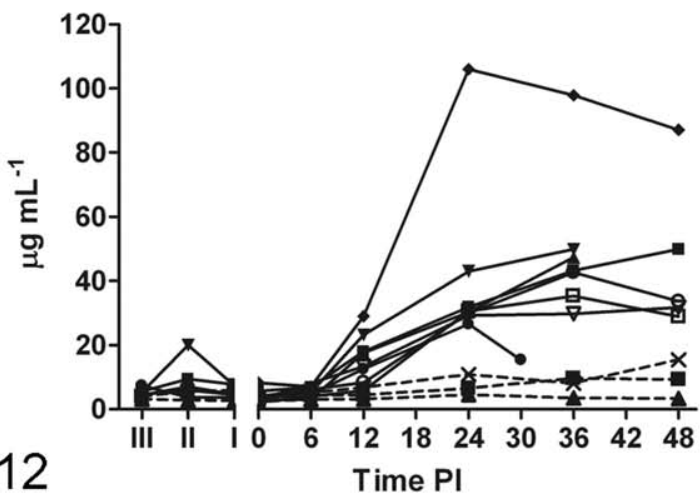

Time PI $\rightarrow-$ Group A

$\mp$ Group B

$\rightarrow$ Group C

$\rightarrow$ Group D

-•-Group E
9
- $\mathrm{HC}-1$

$-\mathrm{HC}-3$

HC-4

- HC-7

-LC-2

- LC-3

- LC-4
Figure 10. Serum levels of interleukin-6 (IL-6) (ng/mL). Notice division of Y-axis, with the highest observed IL-6 levels in LC-I. IL-6 levels of sham-inoculated control animal (LC-4, HC-6, HC-7) were below the detection limit and are therefore not shown (no broken lines). Figure II. Serum levels of tumor necrosis factor alpha $(\mathrm{TNF} \alpha)(\mathrm{ng} / \mathrm{mL})$. Generally a high level of TNF $\alpha$ was observed in HC-5 in measurements both prior to and after inoculation. Figure I2. Serum levels of C-reactive protein (CRP) $(\mu g / \mathrm{mL})$. Figure I3. Serum levels of haptoglobin $(\mathrm{Hp})(\mu \mathrm{g} / \mathrm{mL})$. In all figures, the broken lines represent sham-inoculated control animals and the full lines the infected pigs. First part of the $\mathrm{x}$-axis = reference values from three time points before inoculation (III, II, and I). Last part of the $\mathrm{x}$-axis = hours post inoculation $(\mathrm{PI})$.
TNF- $\alpha$
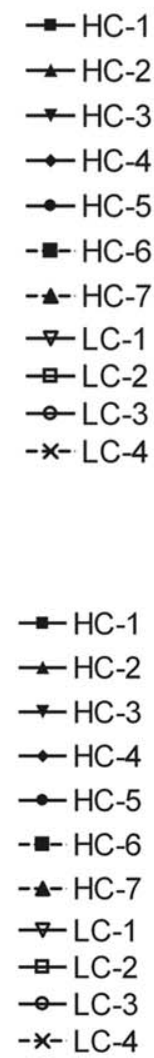

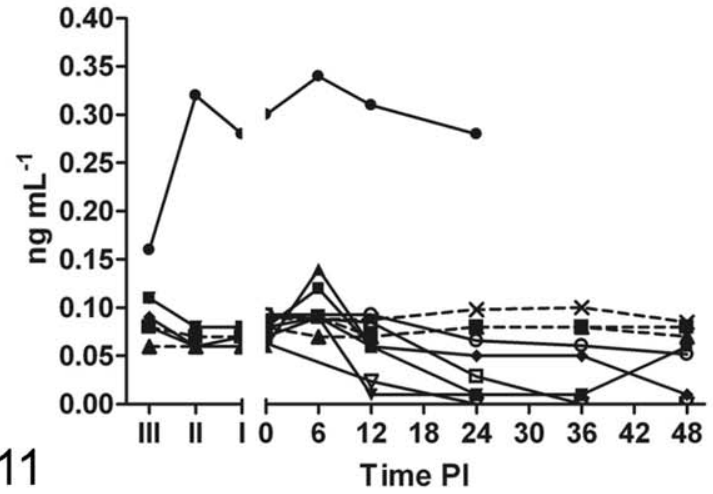

Haptoglobin

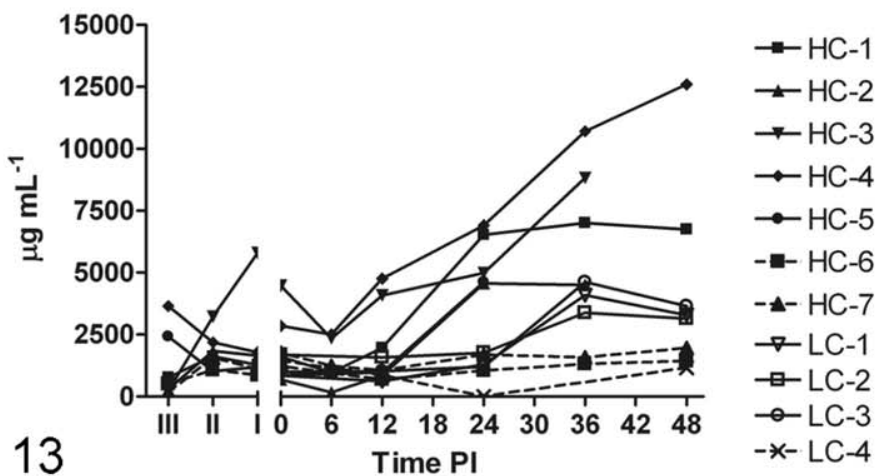



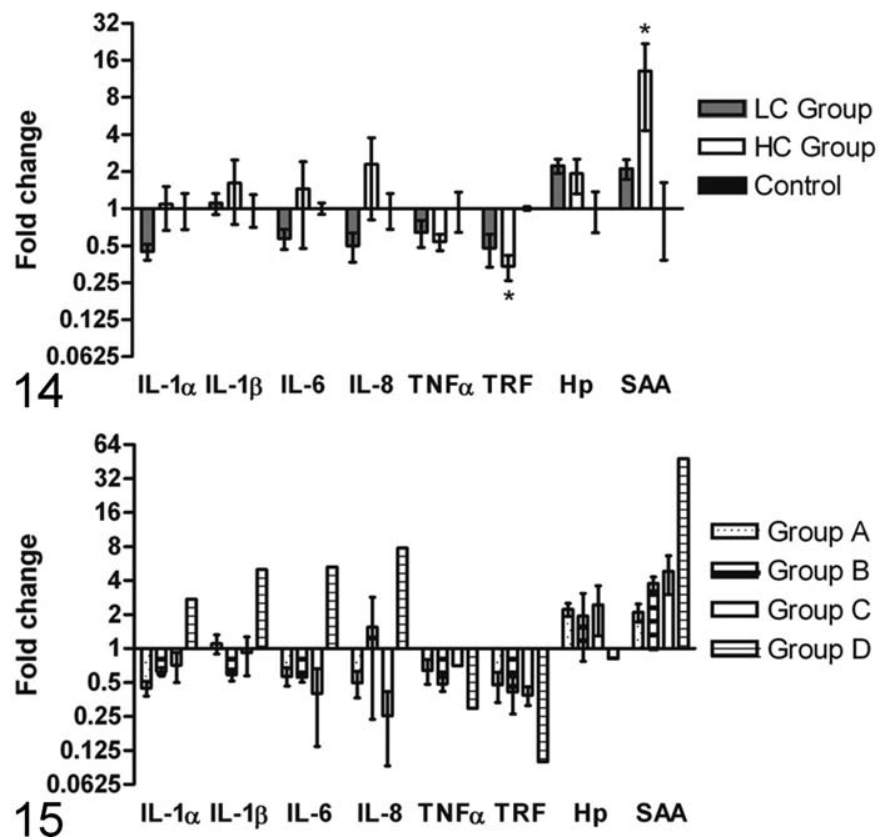

Figure 14. mRNA expression of inflammatory markers in lung tissue, visualized as fold changes for low concentration ( $L C=$ Group $A)$ and high concentration ( $\mathrm{HC}=$ Groupd $\mathrm{B}, \mathrm{C}$, and $\mathrm{D})$ of $S$. aureus compared to sham-inoculated control animals (Control $=$ Group E). Fold changes in the concentration groups ( $\mathrm{LC}$ and $\mathrm{HC}$ ) are shown as increasing or decreasing mRNA expression levels in comparison to the control group. Mean level of the control group was set to I. mRNA levels coding for serum amyloid A (SAA) $(P=.030)$ and transferrin (TRF) $(P=$ .022 ), were found to be significantly up- and-down regulated in the high concentration group compared to the control group, respectively, represented by $*$. Figure 15 . Contributions to the fold changes from the individual infected groups (A, B, C, and D). In both figures, bars represent mean \pm SEM. Y-axis: note logarithmic scale.

through $\mathrm{C}$, compared to the control group. The same groups showed correspondingly minor histological lung lesions (Group A) or focal confinement of major lesions by abscess formation (Groups B and C). In contrast, the lung with more extensive diffuse lesions (Group D/HC-2) showed upregulations of 2 fold to 8 fold in IL- $1 \alpha$, IL- $1 \beta$, IL-6, and IL-8 mRNA levels. Similar up-regulation of mRNA levels of proinflammatory markers have been found in lungs infected with Actinobacillus pleuropneumoniae, where a high degree of tissue destruction and impairment of pulmonary boundaries is normally seen. ${ }^{3,36}$ This suggests that the porcine pulmonary cytokine response could be dependent on the extent of tissue destruction and the degree of confinement or vice versa.

The highest mRNA fold changes of pro-inflammatory cytokines were seen for IL- 8 in Group D/HC-2, corresponding with the more diffuse IL- 8 response detected by IHC in the same pig (HC-2). Previous studies confirm the central role of IL- 8 in the pathogenesis of human $\mathrm{ARDS}^{24}$ and findings of high IL- 8 protein content in the lungs of pigs with sepsis. ${ }^{12}$ An IHC IL-8 response was also detected at the periphery of the abscesses in Groups B and C, equivalent to the location seen by mRNA in situ hybridization in other studies. ${ }^{3,6}$ However, this was contrasted by down-regulation of IL-8 mRNA levels in Group $\mathrm{C}$, which might be explained by the fact that mRNA detection in tissue only reflects the gene expression at the time the sample is taken (eg, time of death in this study) and not necessarily the cytokine protein content, which could be accumulated in the tissue over time. ${ }^{13}$

The mRNA expression of acute phase proteins appeared to be highly induced in the lungs of infected pigs. SAA showed a stepwise increase in mRNA expression when moving from slightly affected to severely affected groups, which may reflect a local, pulmonary synthesis of this acute phase protein and mirror the degree of local tissue damage. SAA mRNA expression was clearly induced more dramatically than any of the other factors investigated. Haptoglobin, a hemoglobin-binding acute phase protein normally produced in the liver, has in previous studies been shown to increase in the serum of pigs with, for example, respiratory infections. ${ }^{22}$ Increased levels of serum Hp were seen in all infected animals but primarily in pigs receiving the $\mathrm{HC}$ dose (HC-1, 3, and 4). However, mRNA expression in pulmonary tissue were almost equally enhanced in Groups A, B, and C, although no increases were seen in the highly diseased pig in Group D. Analysis of pulmonary Hp mRNA expression is complicated by the fact that neutrophils attracted to the lung during inflammation produce $\mathrm{Hp}^{49}$ However, Hp does seem to be highly induced locally in the infected lungs of the pigs in this study, probably as a manner of protection from oxidative damage due to hemoglobin. ${ }^{55}$ This finding supports the theory by Hiss et $\mathrm{al}^{25}$ of $\mathrm{Hp}$ production in bronchial/bronchiolar epithelium in infected porcine lungs, as it is seen in humans and mice. ${ }^{53,54}$ In pigs with pleuropneumonia extra-hepatic Hp mRNA expression was also found in leucocytes, spleen, and lymph nodes. ${ }^{46}$ As expected, mRNA levels of TRF, a negative acute phase reactant, were generally down-regulated in all infected animals but only significantly in the HC group.

All infected animals in both the LC and HC groups developed sepsis and severe sepsis with organ dysfunction (Soerensen et al, unpublished data, 2011), ${ }^{32}$ fulfilling the SIRS criteria by signs of hyperventilation, marked increases in body temperature, and neutrophils. ${ }^{11}$ This was furthermore supported by increased levels of systemic acute phase proteins (CRP and Hp) and IL-6. ${ }^{33}$ Circulating IL-6 has previously been associated with prediction of multiple organ dysfunction in human septic patients. ${ }^{21}$ Nevertheless, no correlation was observed between the severely affected lung with a high IL-6 mRNA level (Group D/HC-2) and high systemic protein levels of IL6. On the contrary, the highest systemic IL-6 level was observed in a pig from the LC group (LC-1), in which local pulmonary mRNA IL-6 levels were down-regulated, thus suggesting that the lungs might not be the main contributor to the increasing systemic IL-6 protein levels. Lack of correlation between organ-specific cytokine expression and plasma cytokines has previously been described in inflammatory porcine models. ${ }^{13,19}$ An ability of the lung to control or compartmentalize the cytokines has been shown by others ${ }^{3}$ and speculations could be made that as a result of bacterial blood clearance in the lungs of the pig, a high degree of pulmonary self-regulation is 
needed to prevent all infections from leading to severe pulmonary impairment and sepsis. This is supported by a porcine endotoxin study by Brix-Christensen et al, ${ }^{12}$ where low cytokine protein content was found in the lung tissue compared to high levels in the kidney, adipose tissue, and liver. Systemic $\mathrm{TNF} \alpha$ levels showed a small, transient peak at $6 \mathrm{~h}$ PI (only observed in HC groups). This does not preclude that a bigger response might have taken place in the unsampled 0 to $6 \mathrm{~h}$ PI time window and that the slightly elevated $6 \mathrm{~h}$ peak represent the decline of a larger peak. It has been shown previously that the TNF $\alpha$ response to Gram-positive infections in pigs might be absent altogether ${ }^{32}$ or smaller and more slowly occurring, ${ }^{44}$ compared to the TNF $\alpha$ response in Gram-negative infections, which are consistently found to be very high and often occurring within the first hour after infection. ${ }^{14,37,42}$ However, one animal (HC-5) showed an abnormally high serum concentration of TNF $\alpha$, which could indicate illness prior to inoculation (initiating at II). However, no other markers of inflammation were suspiciously increased. The great individual variation seen in both the systemic and the local inflammatory response, regardless of concentration, could mimic the large heterogeneity seen in human patients with sepsis. But it also reflects the low power of the study due to the few animals used.

In conclusion, in this study pulmonary clearance was found to be dependent on bacterial concentration of the inoculum rather than the total number of bacteria. Lesion dependent increases in mRNA levels of the acute phase protein SAA appear to reflect the degree of local tissue damage and could be a future target for developing a test for the degree of specific organ lesions. Furthermore, a correlation between the occurrence of nonconfined lesions and increasing mRNA levels of pro-inflammatory cytokines in the lungs was observed for one animal (Group D/HC-2). No obvious correlation was seen between the local pulmonary mRNA expression of inflammatory markers and the systemic levels of inflammatory markers. This could indicate that no major systemic cytokine contributions are seen by spillover from the lungs, despite the porcine PIMs causing a bacterial predisposition for lung lesions. ${ }^{15,41}$

\section{Acknowledgements}

We thank Hanne H. Moeller, Betina Andersen, and Lisbet Kioerboe for their excellent assistance with tissue collection and histological staining procedures. We also thank Karin Tarp Wendt and Henriette Vorsholt for technical assistance with gene expression analysis.

\section{Declaration of Conflicting Interests}

The authors declared no potential conflicts of interest with respect to the research, authorship, and/or publication of this article.

\section{Funding}

The authors disclosed receipt of the following financial support for the research, authorship and/or publication of this article: This work was supported by grant no. 271-07-0417 from the Danish Medical Research Council (Ministry of Science, Technology and Innovation). The gene expression analysis was partly supported by the Danish Research Council for Technology and Production Sciences (274-07-0389).

\section{References}

1. Abraham E, Matthay MA, Dinarello CA, et al. Consensus conference definitions for sepsis, septic shock, acute lung injury, and acute respiratory distress syndrome: time for a reevaluation. Crit Care Med 2000;28(1):232-235.

2. Andersen CL, Jensen JL, Orntoft TF. Normalization of real-time quantitative reverse transcription-PCR data: a model-based variance estimation approach to identify genes suited for normalization, applied to bladder and colon cancer data sets. Cancer Res 2004;64(15):5245-5250.

3. Baarsch MJ, Scamurra RW, Burger K, et al. Inflammatory cytokine expression in swine experimentally infected with Actinobacillus-Pleuropneumoniae. Infect Immun 1995;63(9): 3587-3594.

4. Bancroft J, Gamble M. Theory and Practice of Histlogical Techniques. 6th ed. New York: Churchill Livingstone, Elsevier; 2008.

5. Benfield T, Espersen F, Frimodt-Moller N, et al. Annual report on Staphylococcus aureus bacteraemia cases 2006. http://www.ssi. $\mathrm{dk} /$ Forskning/Infektioner/Systemiske\%20infektioner/ /media/ Indhold/DK\%20-\%20dansk/Forskning/Infektioner/Annual06_3 _rev.ashx. Published 2006. Accessed February 20, 2012.

6. Berndt A, Heller M, Kosmehl H. Cytokine mRNA expression in experimental porcine pneumonia. Dtsch Tierarztl Wochenschr 2002;109(4):205-209.

7. Bhatia M, Moochhala S. Role of inflammatory mediators in the pathophysiology of acute respiratory distress syndrome. J Pathol 2004;202(2):145-156.

8. Bianchi ATJ, Scholten JW, Moonen-Leusen HWM, et al. Development of the natural response of immunoglobulin secreting cells in pigs as a function of organ, age and housing. Dev Comp Immunol 1999;23(6):511-520.

9. Bianchi ATJ, Zwart RJ, Jeurissen SHM, et al. Development of the B- and T-cell compartments in porcine lymphoid organs from birth to adult life: an immunohistological approach. Vet Immunol Immunopathol 1992;33(3):201-221.

10. Bone RC. Toward a theory regarding the pathogenesis of the systemic inflammatory response syndrome: what we do and do not know about cytokine regulation. Crit Care Med 1996;24(1): 163-172.

11. Bone RC, Balk RA, Cerra FB, et al. Definitions for sepsis and organ failure and guidelines for the use of innovative therapies in sepsis. The ACCP/SCCM Consensus Conference Committee. American College of Chest Physicians/Society of Critical Care Medicine. Chest 1992;101(6):1644-1655.

12. Brix-Christensen V, Gjedsted J, Andersen SK, et al. Inflammatory response during hyperglycemia and hyperinsulinemia in a porcine endotoxemic model: the contribution of essential organs. Acta Anaesthesiol Scand 2005;49(7):991-998.

13. Brix-Christensen V, Vestergaard C, Chew M, et al. Plasma cytokines do not reflect expression of pro- and anti-inflammatory cytokine mRNA at organ level after cardiopulmonary bypass in neonatal pigs. Acta Anaesthesiol Scand 2003;47(5):525-531.

14. Castellheim A, Thorgersen EB, Hellerud BC, et al. New biomarkers in an acute model of live Escherichia coli-induced sepsis in pigs. Scand J Immunol 2008;68(1):75-84. 
15. Crocker SH, Eddy DO, Obenauf RN, et al. Bacteremia-hostspecific lung clearance and pulmonary failure. J Trauma 1981; 21(3):215-220.

16. Dehring DJ, Crocker SH, Wismar BL, et al. Comparison of live bacteria infusions in a porcine model of acute respiratory-failure. J Surg Res 1983;34(2):151-158.

17. Dehring DJ, Wismar BL. Intravascular macrophages in pulmonary capillaries of humans. Am Rev Respir Dis 1989;139(4):1027-1029.

18. du Manoir JM, Albright BN, Stevenson G, et al. Variability of neutrophil and pulmonary alveolar macrophage function in swine. Vet Immunol Immunopathol 2002;89(3-4):175-186.

19. Ebdrup L, Krog J, Granfeldt A, et al. Leukocyte, plasma, and organ-associated cytokine profiles in an animal model of acute inflammation. APMIS 2008;116(5):352-360.

20. Falk E, Fallon JT, Mailhac A, et al. Muramidase-a useful monocyte/macrophage immunocytochemical marker in swine, of special interest in experimental cardiovascular-disease. Cardiovasc Pathol 1994;3(3):183-189.

21. Frink M, van Griensven M, Kobbe P, et al. IL-6 predicts organ dysfunction and mortality in patients with multiple injuries. Scand J Trauma Resusc Emerg Med 2009;17:49-55.

22. Heegaard PMH, Klausen J, Nielsen JP, et al. The porcine acute phase response to infection with Actinobacillus pleuropneumoniae. Haptoglobin, C-reactive protein, major acute phase protein and serum amyloid a protein are sensitive indicators of infection. Comp Biochem Physiol B 1998;119(2):365-373.

23. Heegaard PMH, Pedersen HG, Jensen AL, et al. A robust quantitative solid phase immunoassay for the acute phase protein $\mathrm{C}$ reactive protein (CRP) based on cytidine $5^{\prime}$-diphosphocholine coupled dendrimers. J Immunol Methods 2009;343(2):112-118.

24. Hildebrand F, Stuhrmann M, van Griensven M, et al. Association of IL-8-251A/T polymorphism with incidence of Acute Respiratory Distress Syndrome (ARDS) and IL-8 synthesis after multiple trauma. Cytokine 2007;37(3):192-199.

25. Hiss S, Willbrenning GS, Suntz M, et al. Immunohistochemical localization of Haptoglobin in porcine lungs. Anat Histol Embryol 2008;37(3):196-199.

26. Imarisio JJ. Liver scan showing intense lung uptake in neoplasia and infection. J Nucl Med 1975;16(3):188-190.

27. Jensen HE, Nielsen OL, Agerholm JS, et al. A non-traumatic Staphylococcus aureus osteomyelitis model in pigs. In vivo 2010; 24(3):257-264.

28. Johansen LK, Frees D, Aalbaek B, et al. A porcine model of acute, haematogenous, localized osteomyelitis due to Staphylococcus aureus: a pathomorphological study. APMIS 2011;119(2):111-18.

29. Kurahashi K, Kajikawa O, Sawa T, et al. Pathogenesis of septic shock in Pseudomonas aeruginosa pneumonia. J Clin Invest 1999;104(6):743-750.

30. Kvist PH, Bielecki M, Gerstenberg M, et al. Evaluation of subcutaneously-implanted glucose sensors for continuous glucose measurements in hyperglycemic pigs. In vivo 2006;20(2):195-203.

31. Kvist PH, Iburg T, Bielecki M, et al. Biocompatibility of electrochemical glucose sensors implanted in the subcutis of pigs. Diabetes Technol Ther 2006;8(4):463-475.

32. Leifsson PS, Iburg T, Jensen HE, et al. Intravenous inoculation of Staphylococcus aureus in pigs induces severe sepsis as indicated by increased hypercoagulability and hepatic dysfunction. FEMS Microbiol Lett 2010;309(2):208-216.

33. Levy MM, Fink MP, Marshall JC, et al. 2001 SCCM/ESICM/ ACCP/ATS/SIS International Sepsis Definitions Conference. Crit Care Med 2003;31(4):1250-1256.

34. Martin GS, Mannino DM, Eaton S, et al. The epidemiology of sepsis in the United States from 1979 through 2000. N Engl J Med 2003;348(16):1546-1554.

35. Matute-Bello G, Frevert CW, Martin TR. Animal models of acute lung injury. Am J Physiol Lung Cell Mol Physiol 2008;295(3): L379-L399.

36. Mortensen S, Skovgaard K, Hedegaard J, et al. Transcriptional profiling at different sites in lungs of pigs during acute bacterial respiratory infection. Innate Immun 2011;17(1):41-53.

37. Nielsen EW, Hellerud BC, Thorgersen EB, et al. A new dynamic porcine model of meningococcal shock. Shock 2009;32(3): 302-309.

38. Nielsen OL, Iburg T, Aalbaek B, et al. A pig model of acute Staphylococcus aureus induced pyemia [published online ahead of print March 27, 2009]. Acta Vet Scand. doi:10.1186/1751-014751-14

39. Opal SM. Severe sepsis and septic shock: defining the clinical problem. Scand J Infect Dis 2003;35(9):529-534.

40. Pedersen LG, Castelruiz Y, Jacobsen S, et al. Identification of monoclonal antibodies that cross-react with cytokines from different animal species. Vet Immunol Immunopathol 2002;88(3-4): 111-122.

41. Ricci MA, Mehran R, Christou NV, et al. Species differences in the clearance of Staphylococcus aureus bacteremia. J Invest Surg 1991; 4:53-58.

42. Rimmele T, Assadi A, Benatir F, et al. Validation of a Pseudomonas aeruginosa porcine model of septic shock. Journal of Infection 2006;53(3):199-205.

43. Rubenfeld GD, Caldwell E, Peabody E, et al. Incidence and outcomes of acute lung injury. New Engl J Med 2005;353(16): 1685-1693.

44. Saetre T, Hoiby EA, Aspelin T, et al. Acute serogroup A streptococcal shock: A porcine model. J Infect Dis 2000;182(1): 133-141.

45. Singh B, Pearce JW, Gamage LN, et al. Depletion of pulmonary intravascular macrophages inhibits acute lung inflammation. Am J Physiol Lung Cell Mol Physiol 2004;286(2): L363-L372.

46. Skovgaard K, Mortensen S, Boye M, et al. Rapid and widely disseminated acute phase protein response after experimental bacterial infection of pigs [published online ahead of print February 24, 2009]. Vet Res.

47. Soerensen CM, Holmskov U, Aalbaek B, et al. Pulmonary infections in swine induce altered porcine surfactant protein $\mathrm{D}$ expression and localization to dendritic cells in bronchial-associated lymphoid tissue. Immunology 2005;115(4):526-535.

48. Staub NC. Pulmonary intravascular macrophages. Annu Rev Physiol 1994;56:47-67.

49. Theilgaard-Monch K, Jacobsen LC, Nielsen MJ, et al. Haptoglobin is synthesized during granulocyte differentiation, stored in specific granules, and released by neutrophils in response to activation. Blood 2006;108(1):353-361. 
50. Tutor JD, Mason CM, Dobard E, et al. Loss of compartmentalization of alveolar tumor necrosis factor after lung injury. Am J Respir Crit Care Med 1994;149(5):1107-1111.

51. Vandesompele J, De Preter K, Pattyn F, et al. Accurate normalization of real-time quantitative RT-PCR data by geometric averaging of multiple internal control genes [published online ahead of print June 18, 2002]. Genome Biol.

52. Winkler GC. Pulmonary intravascular macrophages in domesticanimal species - review of structural and functional-properties. $\mathrm{Am}$ J Anat 1988;181(3):217-234.
53. Yang FM, Friedrichs WE, Navarijoashbaugh AL, et al. Cell-typespecific and inflammatory-induced expression of haptoglobin gene in lung. Lab Invest 1995;73(3):433-440.

54. Yang FM, Ghio AJ, Herbert DC, et al. Pulmonary expression of the human haptoglobin gene. Am J Respir Cell Mol Biol 2000;23(3):277-282.

55. Yang FM, Haile DJ, Berger FG, et al. Haptoglobin reduces lung injury associated with exposure to blood. Am J Physio Lung Cell Mole Physiol 2003;284(2): L402-L409. 